OPEN ACCESS

International Journal of Management \& Entrepreneurship Research

P-ISSN: 2664-3588, E-ISSN:2664-3596

Volume 2, Issue 5, P.No. 365-379, October, 2020

Fair East Publishers

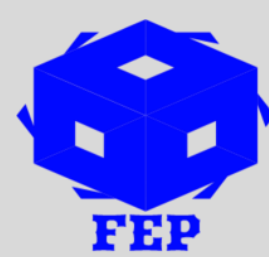

Journal Homepage: www.fepbl.com/index.php/ijmer

\title{
INCORPORATING ICT INTO TEACHING AND LEARNING IN JUNIOR HIGH SCHOOLS IN AJUMAKO: CHALLENGES FOR TEACHERS AND THEIR SUPPORT STRATEGIES
}

\author{
Justice Agyei Ampofo ${ }^{1,3}$, Antwi Abrefi Abigail ${ }^{2}$, Nyatusah Frank Yao ${ }^{3}$ \\ ${ }^{1}$ University for Development Studies, Tamale (Ghana) \\ ${ }^{2}$ University of Professional Studies, Accra (Ghana) \\ ${ }^{3}$ University of Education, Winneba (Ghana)
}

\begin{abstract}
*Corresponding Author: Justice Agyei Ampofo
Corresponding Author Email: papajusty@gmail.com

Article Received: 22-09-20

Accepted: 05-10-20

Published: $15-10-20$

Licensing Details: Author retains the right of this article. The article is distributed under the terms of the Creative Commons Attribution-NonCommercial 4.0 License (http://www.creativecommons.org/licences/by-nc/4.0/) which permits non-commercial use, reproduction and distribution of the work without further permission provided the original work is attributed as specified on the Journal open access page.
\end{abstract}

\section{ABSTRACT}

The study aimed at examining the challenges the basic school teachers in Ajumako Township face in incorporating ICT into teaching and learning as well as the support systems available to them. The descriptive survey design was employed for this study. The researcher used questionnaire as the main instruments for data collection. The target population for the study was all the basic school teachers in Ajumako of the Central Region of Ghana. In all, 40 teachers were used for the study. Simple random sampling strategy under the probability sampling technique was employed to select respondents for the study. Percentages were used for the analysis of the response. It emerged from the study that availability of ICT resources, students' readiness to embrace technology, teachers' readiness to embrace technology, availability of technical support, stable power supply and intention to facilitate teaching and learning are the factors that influence the teachers' usage of ICT resources in teaching and learning in basic schools in Ajumako. The study also found out that providing effective pedagogical strategies for effective ICT introduction, offering opportunity to observe teachers who use technology virtually or in real practice, augmenting curriculum with technologyenhance instructions, providing freedom for teachers in selecting and using curriculum and provision of effective, timely and continuous training to improve ICT skills and manage a technology-rich classroom are the support systems available for the teachers to incorporate ICT into teaching and learning. Based on the findings, it was recommended that ICT basic 
resources like computers, laptops and infrastructures should be provided to basic schools in Ajumako of the Central Region of Ghana for effective use of ICT in teaching and learning since it is the basic stage of equipping the youth with the necessary skills and knowledge for national development. Teachers should also be given the necessary training in ICT usage so that they become familiar with modern pedagogy of imparting knowledge and skills, and possibly become part of curriculum structure for their professional training.

Keywords: Incorporating, ICT, Teaching, Learning, Junior High Schools, Ajumako, Challenges, Teachers, Support Strategies.

\section{INTRODUCTION}

Information and Communication Technology (ICT) has become, within a very short time, one of the basic building blocks of modern society. Many countries now regard the mastering of the basic skills and concepts of ICT as part of the core of education, alongside reading, writing and numeracy. At every level of education, ICT is perceived as a vehicle for curriculum enhancement. ICT (Wijewardena, 2002). Zhao (2002) assert that the role of ICT in teaching and learning is rapidly becoming one of the most important and widely discussed issues in contemporary education policy.

The emphasis on incorporating of ICT into all subjects in Ghanaian schools has become more urgent considering the prevailing teacher-dominated approach to schooling and teaching in the country. Learning is largely passive and products of the schools are rated low in creativity, critical thinking and problem-solving, apparently because the schools have failed to develop such skills in students (Tomei, 2005). Teachers who are supposed to be effective agents of ICT incorporating at times are unable to incorporate ICT in their teaching for a number of reasons. Teachers in the Ghanaian Basic Cycle Schools are no exception. In the words of Zhao, Pugh, Sheldon and Byers, (2002, p. 511), “...teachers need to know the affordances and constraints of various technologies and how specific technologies might support their own teaching practices and curricular goals. They also need to know how to use technologies."

For the achievement of full ICT incorporating into all subjects, there is the need to find out the reasons why teachers are unable to incorporate ICT in their teaching. Much of early research on ICT use in education has ignored teachers' perception toward ICT. Such studies only focused on ICT and their effects on teachers' competence; thus, overlooking the psychological and contextual factors involved in ICT applications. It must be stated that teachers' perception towards ICT is also related to their ICT competence because according to Schoepp (2005), people's perception toward a new technology is the key element in its adoption. This suggests that studies at the early stages of ICT integration should focus on teachers or the end-user's perception toward ICT. Specifically, the study sought to:

1. Explore the challenges teachers face in basic school in Ajumako in incorporating ICT into teaching and learning?

2. Find out the support systems available to teachers in an effort to incorporate ICT in teaching and learning? 


\section{REVIEW OF RELATED LITERATURE Information and Communication Technology}

According to Lever-Duffy, McDonald and Mizell, (2003), ICT comprises the use of at least a computer and the internet as well as computer hardware and software, networks, and a host of devices that convert information (text, images, sounds, and motion) into general digital formats. Information and communication technology (ICT), in this context, represent a new approach for enhancing the dissemination of information and will be used, applied, and incorporating it into learning on the basis of conceptual understanding and from the earliest times when computers were commercially available, they could be found in use in educational institutions, and educators (Bork, 1980; Becker, 1999; Bracey, 2005; Wachira, 2005; Ampofo, 2019) argued that computers should be used to support learning.

\section{Challenges Teachers face in Incorporating ICT into Teaching and learning}

The act of incorporating ICT into teaching and learning is a complex process and one that may encounter a number of difficulties. These difficulties are known as "barriers" (Amedahe, 2010). A barrier is defined as, "any condition that makes it difficult to make progress or to achieve an objective" (Wellman, 2002; Boakye, 2008). The objective being analysed in this study is successful ICT incorporation in subjects.

It is a common misconception that access to technology on its own motivates teachers to apply it in their teaching. The biggest barriers to the use of computers identified by teachers participating in the 1998-1999 survey assessing the World Links schools programme were the lack of time available in classes, and in their own schedules for planning; and the lack of a national policy on the use of computers in schools (Kozma, McGhee, Quellmalz and Zalles, (2004), p. 376). Relatively, few teachers identified infrastructure problems such as, the lack of computers in working condition, unreliable electricity or lack of access to the internet, although these varied by country (Dellit, 2002). As few technologically advanced countries joined the programme in 1999-2000, the major barriers to ICT classroom use became the lack of computer hardware $(60 \%)$, software $(56 \%)$ and reliable internet. There is also a general inadequacy of learning resources, course curricula and other learning materials (52\%), particularly in African countries such as Mauritania, Ghana and Zimbabwe.

Lack of access to technology is inevitably a major barrier in its application, but availability does not necessarily translate into use. However, a study of Nigerian basic school teachers by Tella, Tella, Toyobo, Adika and Adeyinka (2007) found that, lack of technical support in the schools, and teachers' lack of expertise in using ICT were the prominent factors hindering teachers' readiness and confidence in using ICT (Harris, 2002; Demetriadis et al, 2003). When asked to rank a list of factors which might deter them from making greater use of ICT in their classroom teaching, teachers in the UK had this to say, 'lack of time to plan how to incorporate the use of computers into lessons emerged as the most influential and the most commonly mentioned barrier to ICT use.' It was mentioned as a deterrent by 30 out of 42 respondents.

The third most influential factor, according Tella et al (2007) was, 'pressure to cover curriculum content.' Factors which were seldom mentioned as deterrents, or which were low on the list of teachers' concerns were; lack of confidence/knowledge of how computers work, anxiety about the classroom management implications of the use of computers, ideological resistance to the use of computers (they do not believe that computers have much to offer in 
developing pupils' knowledge and understanding). Teachers, like other people, use ICT in their activities outside school (Thomas, 2005). It is remarkable that this use does not transform to teaching, although it does transform teachers' professional activities such as preparing lessons or administration.

\section{Support Systems for Teachers to Incorporate ICT into Teaching and Learning}

Noticeably, teachers who usually take decisions, including ICT incorporation in the classroom often does so base on their beliefs about good learning and what fits easily into the existing conceptual and social organization of classroom (Hepp, 2004). Teachers intensively used information technology to emphasize the importance of using ICT for facilitating students' participation in progressive inquiry, collaborative learning, and the learners' active engagement in the knowledge formation process (Munro, 2000). Teachers with good ICT skills used ICT more, and more often in a student-centered way (Moore, 2000) and they appeared to have adequate pedagogical means for pursuing new pedagogical practices (Martin, 2003). Hence the call for ICT incorporating in the Ghana education system cannot be realized without promoting ICT use among teachers.

In a study to explore the perceptions of students, teachers and education officers in Ghana on the role of the computer and the teacher for quality teaching and learning and by Nichol (2003), the result showed that students, teachers and education officers recommended the teachers should be trained to acquire computer skills (Hennessy, 2003). Teachers should be given the necessary training in ICT usage so that they become familiar with modern pedagogy of imparting knowledge and skills (OECD, 2004).

Many researchers into technology incorporation believes the availability and the accessibility to ICT facility can make significant impact on teachers' use of ICT. Insufficient number of computers, access to technology and time for practice that have been identified certain important obstacle in the realisation of computer-related goals in schools that need to be dealt with. Hence the provision of ICT infrastructure and increase accessibility has been proposed and recommended (Smeets, 2005).

\section{METHODOLOGY}

\section{Research Methods}

A mixed method approach was adopted for this study, involving both qualitative and quantitative data collection methods. Quantitative data was collected using questionnaires. These tools captured the required data on challenges the teachers face in incorporating ICT into teaching and learning and the support systems available for the teachers to incorporate ICT into teaching and learning. Qualitative data was captured using Key Informants Interview (KII) guides with key stakeholders at the school levels. Specific key stakeholders were asked questions that are relevant to this study.

Mixed method approaches was used for this study because it can answer a broader and more complete range of research questions because the researcher is not confined to a single method or approach (Ampofo, 2020). Mixed-methods can also provide stronger evidence for a study's conclusions through convergence and corroboration of findings (Ampofo, 2019). The researcher used a concurrent mixed methods design in the current study. In a concurrent approach, two or more data collection instruments are administered within the same time frame. The researcher collected both forms of data (questionnaire and interview) at the same 
time during the study, and then integrated these data into the interpretation of the overall results (Creswell, 2013; Ampofo, 2020).

The purpose of using a mixed method design was to use both the responses obtained from the questionnaire and those from the interviews to provide a comprehensive analysis of the research questions asked. A secondary reason was the possibility of using the results from one instrument to confirm or corroborate findings from the other (Ampofo, 2019).

\section{Research Design}

The research is a descriptive survey through which views and opinions were sampled from teachers. Ampofo (2019) views descriptive survey as a design that portrays accurately the characteristic of particular individual situations or groups. In other words, the descriptive survey is a research method that is non-experimental and deals with the relating among nonmanipulated variable. A descriptive survey also provides a quantitative or numeric description of trends, attitudes, or opinions of a population by studying a sample of that population. It includes cross-sectional and longitudinal studies using questionnaire or structured interviews for data collection, with the intent of generalizing from a sample to a population (Ampofo, 2019).

Descriptive survey design also helped achieved the goal of the study, which was to examine the challenges the basic school teachers in Ajumako township face in incorporating ICT into teaching and learning as well as the support systems available to them. The study identified the ICT resources available to the teachers, the factors influencing the usage of these resources in teaching and learning. It also examined the challenges they face and how they are supported for effective usage of the resources.

\section{The Study Area}

The study was conducted in all the four public Junior High Schools in Ajumako in the Central Region of Ghana. The researcher's work experience as a teacher has helped me gain access to the information needed for the successful completion of this study. The schools are within my locality hence reducing the cost as well as risk involved in travelling. This makes the data collection process easy and convenient.

\section{Population}

The target population consisted of the teachers of the four selected public Junior High Schools in Ajumako. The four public Junior High Schools have a teacher population of about 40 teachers. The teachers are the targeted group because they are teaching and incorporating ICT into teaching and learning is of more relevant to them. This is represented in Table 1.

\section{Table 1}

$$
\begin{gathered}
\frac{\text { Sample Size }}{\text { Teachers }} \\
\frac{\text { Population } \quad 40}{\text { Sampled } \quad 40} \\
\text { Source: Field Survey (2017) }
\end{gathered}
$$

\section{Sample Size and Sampling Techniques}

All the teacher of the four public Junior High Schools were purposively selected for this study. Here all teachers were considered because they are those that are teaching and know the challenges of the ICT incorporation into Junior High Schools. A census survey was conducted. A census survey was conducted among the 40 teachers. According to Cooper and 
Schindler (2000, p.164) "a census is feasible when the population is small and variable, any sample we may draw may not be representative of the population from which it is drawn". Considered the target population in question (Teachers in Ajumako Township Public Junior High School), it is most appropriate to use the census survey.

\section{Instrumentation}

Questionnaire was used to collect data from respondents in this study. The questionnaire was both close ended and open ended questions with options like (Very common, Common, Uncommon, Very uncommon, strongly agree, Agree, Disagree, Strongly Disagree and Ranking). It was divided into three sections which are as follows: Section A - Personal data and Section B on the challenges the teachers face in incorporating ICT into teaching and learning and Section E on the support systems available for the teachers to incorporate ICT into teaching and learning. Questionnaires required less time and money compared to other methods like focus group discussions (Ampofo, 2020).

\section{Pretesting of the Instrument}

A pilot study was conducted in Roman Catholic Junior High School which has the same socio- demographic as that of four selected public Junior High School for this study. The questionnaires were administered to ten (10) teachers. The pilot study was done to improve the reliability of instrument. Changes were made to questions deemed inappropriate after the pilot study.

\section{Validity of the Instruments'}

A research instrument is said to be valid when it measures what it is supposed to measure. Face validity is in relation to the misunderstanding and misinterpretation of the question. This was checked by way employing pretesting method. Content validity on the other hand refers to the capacity of the instrument to prove adequate coverage of a topic. Adequate preparation of the instrument under guidance of the supervisor, expert opinion and pre-testing of the question helped established the content validity.

\section{Reliability of the Study}

Reliability has to do with an instrument consistently producing the same result every time it is used. The test retest method was used to test for the reliability of the instrument. The questionnaires were administered to teachers of Ajumako Roman Catholic Junior High School which has the same socio- demographic as that of the four selected public Junior High Schools for this study. The same questionnaires were administered to them after two weeks. A correlation coefficient of 0.8 alpha levels was obtained which is considered reliable.

\section{Data Collection Procedure}

The researchers obtained an introductory letter from the Department of Psychology and Education, University of Education stating the purpose and objectives of the study and the cooperation of the research participants. The introductory letter was copied to the Ajumako District Educational Directorate and the head teachers of the four selected public Junior High Schools to seek their approval and access to the school, students and other documents that would facilitate the study. The head teacher of the school conveyed a meeting with teachers to inform them about the purpose of the research and their cooperation. The participants were told of the purpose, time, venue and how to answer the questionnaires. They were also assured of their confidentiality and anonymity. The researchers self-administered the questionnaires to 
all the forty (40) teachers selected for the study to clarify issues that are not understandable to them.

\section{Data Analysis Technique}

Analysis of data provided facts and figures that enabled interpretation of the results and reaching conclusions from the findings of the study. All items of the questionnaires were coded. Items in the form of Likert scale were rated between 4-1, with 4 being the highest and 1 being the lowest. Questionnaires were edited to ensure that clear, legible, relevant, and appropriate responses had been provided. The coded items and their corresponding frequencies were fed into the computer using the SPSS software programme. Data were analyzed using simple percentages and frequencies.

\section{RESULTS AND DISCUSSION OF RESULTS}

\section{Demographic Characteristics of Respondents (Teachers)}

One item of the questionnaire gathered data on the respondents (teachers) gender which is presented in the table below.

Table 2
Sex Distribution of Respondents
\begin{tabular}{lll}
\hline Sex & $\mathbf{( F )}$ & $\mathbf{( \% )}$ \\
\hline Male & 25 & 62.5 \\
Female & 15 & 37.5 \\
\hline Total & $\mathbf{4 0}$ & $\mathbf{1 0 0}$ \\
\hline
\end{tabular}
Source: Field Survey $(2017)$

The sex distribution of teachers respondents show that majority of respondents were males as males represented as $25(62.5 \%)$ and $15(37.5 \%)$ were females. The implication is that, male respondents outnumbered female respondents. This finding is in disagreement with Amedahe (2010) who reveal that, most female teachers are in teaching in urban areas of Ghana. The findings of this study is also in disagreement with a study by Bracey (2005), it could be partly due to female teachers joining their husbands who work in urban areas hence avoid working in rural areas.

Another aspect of the questionnaire gathered data on the age distribution of respondents and this is what Table 3 presents.

Table 3

\begin{tabular}{|c|c|c|}
\hline \multicolumn{3}{|c|}{ Age of Respondents (Teachers) } \\
\hline Age Range & (F) & $(\%)$ \\
\hline $18-23 y r s$ & - & - \\
\hline $24-29 y r s$ & 2 & 5.0 \\
\hline $30-34 y r s$ & 8 & 20.0 \\
\hline $41-45 y r s$ & 10 & 25.0 \\
\hline $46-50 y r s$ & 20 & 50.0 \\
\hline $51-55 y r s$ & - & - \\
\hline $56-60$ & - & - \\
\hline Total & 40 & 100 \\
\hline
\end{tabular}

The results form Table 3 shows that majority of respondents were between the age group 4650 representing $20(50.0 \%)$, followed by those between the age group of 41-45 representing $10(25.0 \%)$, followed by those between the age group 30-34 representing 8 (20.0\%), followed 
by those between the age group 24-29 representing 2 (5.0\%). The implication is that, majority of the teachers teaching in basic schools in Ajumako of the Central Region of Ghana were older form 30 years.

Another aspect of the questionnaire gathered data on the teaching experience of respondents and this is what Table 4 presents.

\section{Table 4}

\begin{tabular}{|c|c|c|}
\hline \multicolumn{3}{|c|}{ Teaching experience } \\
\hline Range of Years & Frequency & Percentage \\
\hline 1 month $-2 y r s$ & - & - \\
\hline $2 \mathrm{yrs}-3 \mathrm{yrs}$ & 2 & $5.0 \%$ \\
\hline $4 y r s-5 y r s$ & 8 & $20.0 \%$ \\
\hline Above 5 yrs & 30 & $75.0 \%$ \\
\hline Total & 40 & $100 \%$ \\
\hline
\end{tabular}

From Table 4 the most opted number of years of teaching experience was above 5 years. Seventy five percent of the teachers had teaching experiences above five years, $20 \%$ for $4-5$ years and 5\% for the 2-3 years of teaching. It can be assumed that, all the teachers have adequate work experience and can provide reliable information for the study.

Table 5

\begin{tabular}{lll}
\multicolumn{3}{l}{ Highest Level of Education Attained (Teachers) } \\
\hline Response & Frequency & Percent \\
\hline Diploma & 35 & $87.5 \%$ \\
First Degree & 5 & $12.5 \%$ \\
Masters & - & - \\
\hline Total & $\mathbf{4 0}$ & $\mathbf{1 0 0 . 0}$ \\
\hline \multicolumn{2}{c}{ Source: Field Survey (2017) }
\end{tabular}

Table 5 shows that $35(87.5 \%)$ the respondents had a first degree with the remaining 5 $(12.5 \%)$, have a first degree. A deduction from the above is that majority of the respondents are diploma holders teaching at the four selected basic schools in Ajumako of the Central Region of Ghana.

\section{Analysis of Items}

The analysis of the items are based on the four research questions which are as follows:

3. What are the challenges teachers face in the basic school in Ajumako in incorporating ICT into teaching and learning?

4. What are the support systems available to teachers in an effort to incorporate ICT in teaching and learning?

\section{Research Question One (1)}

The first research question sought to find out challenges teachers face in the basic school in Ajumako in incorporating ICT into teaching and learning. This response is presented in the below table.

Table 6

Challenges teachers face in the basic school in Ajumako in incorporating ICT into teaching and learning

\begin{tabular}{cllll}
\hline Factors & Agreed & Disagreed & F & \% \\
\hline 1. Lack of time to use computers & 40 & - & 40 & $100 \%$ \\
\hline
\end{tabular}


2. Lack of knowledge about computers

3. Lack of confidence

4. Fears to use computers

5. Not sure how useful computers are

6. Computers are not accessible

7. Management do not care if I use ICT or not

8. Computer equipment is unreliable

9. Unstable power supply

10. Limited technology infrastructure (especially internet access

11. Limited hardware and software provision

12. Lack of technical support for computer usage

13. General inadequacy of learning resources, course curricula and other learning materials that incorporate ICT use

14. High cost of ICT equipment and materials
$(100.0 \%)$

\begin{tabular}{|c|c|c|c|}
\hline $\begin{array}{l}30 \\
(75.0 \%)\end{array}$ & $10(25.0 \%)$ & 40 & $100 \%$ \\
\hline $\begin{array}{l}30 \\
(75.0 \%)\end{array}$ & $10(25.0 \%)$ & 40 & $100 \%$ \\
\hline $\begin{array}{l}30 \\
(75.0 \%)\end{array}$ & $10(25.0 \%)$ & 40 & $100 \%$ \\
\hline $\begin{array}{l}40 \\
(100.0 \%)\end{array}$ & - & 40 & $100 \%$ \\
\hline $\begin{array}{l}40 \\
(100.0 \%)\end{array}$ & - & 40 & $100 \%$ \\
\hline $\begin{array}{l}40 \\
(100.0 \%)\end{array}$ & - & 40 & $100 \%$ \\
\hline $\begin{array}{l}40 \\
(100.0 \%)\end{array}$ & - & 40 & $100 \%$ \\
\hline- & $\begin{array}{l}40 \\
(100.0 \%)\end{array}$ & 40 & $100 \%$ \\
\hline $\begin{array}{l}40 \\
(100.0 \%)\end{array}$ & - & 40 & $100 \%$ \\
\hline $\begin{array}{l}40 \\
(100.0 \%)\end{array}$ & - & 40 & $100 \%$ \\
\hline $\begin{array}{l}40 \\
(100.0 \%)\end{array}$ & - & 40 & $100 \%$ \\
\hline $\begin{array}{l}40 \\
(100.0 \%)\end{array}$ & - & 40 & $100 \%$ \\
\hline $\begin{array}{l}40 \\
(100.0 \%)\end{array}$ & - & 40 & $100 \%$ \\
\hline
\end{tabular}

Source: Field Survey (2017)

Table 6 above reveals the challenges teachers face in the basic school in Ajumako in incorporating ICT into teaching and learning. There are 14 items which provided responses on the Challenges teachers face in the basic school in Ajumako in incorporating ICT into teaching and learning. All the respondents 40 (100\%) agreed that lack of time to use computers is a challenge teacher face in incorporating ICT into teaching and learning in basic schools. Also majority of respondents $30(75.0 \%)$ agreed that lack of knowledge about computers is a challenge teachers face in incorporating ICT into teaching and learning whiles $10(25 . .0 \%)$ disagreed that lack of knowledge about computers is a challenge teachers face in incorporating ICT in teaching and learning at basic schools.

Again, majority of respondents $30(75.0 \%)$ agreed that lack of confidence to use computers is a challenge basic school teachers in Ajumako face to incorporate ICT in teaching and learning whiles $10(25.0 \%)$ disagreed that lack of confidence is a challenge teachers face in incorporating ICT in teaching and learning. 30 (75.0\%) agreed that fears to use computers is a challenge basic school teachers in Ajumako face to incorporate ICT in teaching and learning while $10(25.0 \%)$ disagreed that fears to use computers is a challenge teachers face in incorporating ICT into teaching and learning.

Moreover all the respondents $40(100 \%)$ agreed that not sure how useful computers are, computers are not accessible, management do not care if I use ICT or not and computer equipment is unreliable are challenges teachers face in incorporating ICT into teaching and learning. Furthermore, all the respondents 40 (100\%) disagreed that unstable power supply is a challenge that teachers face in incorporating ICT into teaching and learning in basic schools in Ajumako in the Central Region of Ghana. 
In addition, all the respondents 40 (100\%) respectively agreed that limited technology infrastructure (especially internet access, limited hardware and software provision, lack of technical support for computer usage, general inadequacy of learning resources, course curricula and other learning materials that incorporate ICT use and high cost of ICT equipment and materials is a challenge teachers face in incorporating ICT into teaching and learning at basic schools in Ajumako.

The above results are consistent with a study by Schoepp (2005) who asserted that the act of incorporating ICT into teaching and learning is a complex process and one that may encounter a number of difficulties. These difficulties are known as "barriers". According to Zhao (2002) educational factors including levels of teachers own education and literacy rates, and access to professional development play an important role. Indeed, many studies indicate that it is teachers' attitudes, expertise, lack of autonomy and lack of knowledge to evaluate the use and role of ICT in teaching (or technophobia in teachers) that are the prominent factors hindering teachers' readiness and confidence in using ICT support.

A study by Tella, Tella, Toyobo, Adika and Adeyinka (2007) also confirms that lack of access to technology is inevitably a major barrier in its application, but availability does not necessarily translate into use. The author further added that lack of technical support in the schools, and teachers' lack of expertise in using ICT were the prominent factors hindering teachers' readiness and confidence in using ICT.

Also Tella et al (2007) asserted that, a list of factors which might deter teachers from making greater use of ICT in their classroom teaching such as lack of time to plan how to incorporate the use of computers into lessons emerged as the most influential and the most commonly mentioned barrier to ICT use Tella et al (2007) also postulated that pressure to cover curriculum content, lack of confidence/knowledge of how computers work; anxiety about the classroom management implications of the use of computers; ideological resistance to the use of computers (they do not believe that computers have much to offer in developing pupils' knowledge and understanding) are challenges teachers face to incorporate ICT into teaching and learning.

\section{Research Question Two (2)}

The fourth research question sought to find out the support systems available to teachers in an effort to incorporate ICT in teaching and learning. This response is presented in the below table.

Table 7

Support Systems Available to Teachers in An Effort to Incorporate ICT in Teaching and Learning

\begin{tabular}{|c|c|c|c|c|c|}
\hline Factors & & Agreed & Disagreed & $\mathbf{F}$ & $\%$ \\
\hline 1. & $\begin{array}{l}\text { Introduction of pre-service and in-service training for teacher in } \\
\text { ICT }\end{array}$ & $\begin{array}{l}40 \\
(100.0 \%)\end{array}$ & - & 40 & $100 \%$ \\
\hline 2. & Provision of adequate equipment for teaching and learning & $\begin{array}{l}40 \\
(100.0 \%)\end{array}$ & - & 40 & $100 \%$ \\
\hline 3. & $\mathrm{t}$ in schools & $\begin{array}{l}40 \\
(100.0 \%)\end{array}$ & - & 40 & $100 \%$ \\
\hline & $\begin{array}{l}\text { Public Private partnership is key to re } \\
\text { computers and ICT tools for teaching }\end{array}$ & $\begin{array}{l}40 \\
(100.0 \%)\end{array}$ & - & 40 & $100 \%$ \\
\hline & $\begin{array}{l}\text { Sensitization of stakeholders on the benefits of ICT in teaching } \\
\text { and learning }\end{array}$ & $\begin{array}{l}40 \\
(100.0 \%) \\
\end{array}$ & - & 40 & $100 \%$ \\
\hline
\end{tabular}




\begin{tabular}{|c|c|c|c|c|c|}
\hline 6. & $\begin{array}{l}\text { Establish effective monitoring mechanism to ensure effective } \\
\text { ICT integration in teaching and learning }\end{array}$ & $\begin{array}{l}40 \\
(100.0 \%)\end{array}$ & - & 40 & $100 \%$ \\
\hline 7. & $\begin{array}{l}\text { ICT integration should be designed to meet specific and } \\
\text { peculiar needs students }\end{array}$ & $\begin{array}{l}40 \\
(100.0 \%)\end{array}$ & - & 40 & $100 \%$ \\
\hline 8. & $\begin{array}{l}\text { Provision of a desirable level of access to ICT for teachers and } \\
\text { students to use to share digital resources from any learning in } \\
\text { the school }\end{array}$ & $\begin{array}{l}40 \\
(100.0 \%)\end{array}$ & - & 40 & $100 \%$ \\
\hline 9. & $\begin{array}{l}\text { Teachers and students should have a positive attitude towards } \\
\text { the use of ICT in teaching and learning }\end{array}$ & $\begin{array}{l}40 \\
(100.0 \%)\end{array}$ & - & 40 & $100 \%$ \\
\hline
\end{tabular}
Source: Field Survey, 2017

Table 7 above reveals the support systems available to teachers in an effort to incorporate ICT in teaching and learning in basic schools in Ajumako of the Central Region of Ghana. All the respondents $40(100 \%)$ agreed respectively each that introduction of pre-service and inservice training for teacher in ICT, provision of adequate equipment for teaching and learning, ICT should be an elective subject in schools, public private partnership is key to resource the school lab with computers and ICT tools for teaching and learning, sensitization of stakeholders on the benefits of ICT in teaching and learning, effective monitoring mechanism to ensure effective ICT integration in teaching and learning, ICT integration should be designed to meet specific and peculiar needs students, provision of a desirable level of access to ICT for teachers and students to use to share digital resources from any learning in the school and teachers and students should have a positive attitude towards the use of ICT in teaching and learning are the support system available to basic school teachers in Ajumako to incorporate ICT in teaching and learning.

The above results is consistent with a study by Ampofo (2017) who asserted that rather than only providing education theories, ICT researchers should also document examples of how teachers accomplish meaningful and effective technology incorporation to meet their pedagogical goals and needs. This supports the position of Smeets (2005) who reviewed the existing literature on the necessary elements to enable pre-service and in-service teachers to apply ICT as a meaningful pedagogical tool. They recommended that schools provide teachers with solid evidence supporting the positive impact of technology-based and student-centered instruction on student learning and achievement on standardized tests. For instance, schools can provide opportunities for pre-service teachers to observe a variety of examples and models, which they can then apply with real learners. Schools need to help pre-service teachers understand difficulties they may face when they begin to use ICT in their classrooms, and present effective strategies for addressing them. Boakye (2008), also recommend the following strategies to facilitate the learning process; more induction, orientation, and training for students; an increased emphasis on the importance of instructor access and effective administration; and the expansion of podcasting and online conferencing tools. In general, capacity building, curriculum development, infrastructure, policy, and government support are required in order to lower student barriers and improve the effectiveness of ICT use in the classroom. In addition, Bracey (2005) encourage students to acquire specific technical skills to facilitate learning in ICT environments.

According to Amedahe (2010), teachers should learn not only how to use technology to enhance traditional teaching or increase productivity, but also should learn from a student centered perspective how ICT can be introduced into nursing education classroom activities in 
order to promote student learning. This means that teachers need to use ICT in more creative and productive ways in order to create more engaging and rewarding activities and more effective lessons (Dellit, 2002).

Demetriadis (2003) posit that effective instruction is not just a matter of standing or sitting in front of a class and dishing out information to a group of students whose heads are perceived as empty and therefore required to be filled. Instruction requires adequate preparation and planning in terms of how to combine Artistic Knowledge and Skills (AKS), Pedagogical Knowledge and Strategies (PKS) and Technological Knowledge and Skills (TKS) to effectively present the instructional content in a learning situation so as to enhance the learners' achievements, Hence, Ampofo (2019) suggested that teachers keep an open mind about ICT incorporation in classroom. It is imperative that teachers learn new teaching strategies to adapt to the new instruments when teaching with technology.

Boakye (2008) suggested that schools need to provide appropriate access to technology. Furthermore, schools and related institutional systems need to employ new policies to involve teachers in the decision-making and planning processes regarding ICT in their classrooms. Lim (2007) conducted a qualitative study examining effective and ineffective ICT incorporation in schools in order to provide tangible solutions. The results showed that the availability of ICT tools, the establishment of disciplinary and educational principles and procedures, as well as the division of labor among teachers, teaching assistants and students are crucial elements to establishing a well-managed ICT-integrated class. By emphasizing these elements, a learning process that is more likely to engage students in higher-order thinking can be facilitated.

\section{SUMMARY OF MAJOR FINDINGS}

\section{Key Findings of the Study}

A descriptive survey was employed for the study. A questionnaire was used to gather data from basic school teachers in Ajumako and selected through stratified and simple random sampling. The collected data was analyzed in simple percentages.

The first research question was to identify the challenges the teachers face in incorporating ICT into teaching and learning. The study found out that lack of training in the use of computers and other ICTs, lack of knowledge about the use of computers, little previous experience, computer equipment being unreliable, computers not accessible, lack of time to use the computers, lack of confidence in the usage of the computers and time table constraints are the challenges the teachers in basic schools in Ajumako face in incorporating ICT into teaching and learning.

The second research question was to identify the support systems available for the teachers to incorporate ICT into teaching and learning. The study found out that encouraging students to acquire specific technical skills to facilitate learning in ICT environments, appropriate and adequate access to technology, provision of professional development programme ICT to update teachers skills and knowledge, offering technical support to student and teachers, providing effective pedagogical strategies for effective ICT introduction, offering opportunity to observe teachers who use technology virtually or in real practice, augmenting curriculum with technology-enhance instructions, providing freedom for teachers in selecting and using curriculum and provision of effective, timely and continuous training to improve ICT skills 
and manage a technology-rich classroom are the support systems available for the teachers to incorporate ICT into teaching and learning.

\section{CONCLUSIONS}

It can be concluded that, most of the respondents are aware of the importance of ICTs but they do not have the requisite training and skill for effective introduction of ICT in teaching and learning at basic schools. Those who have them basically use them for entertainment or relaxation. This conclusion was arrived at because despite the fact that respondents were aware of the benefits of computers without the requisite know how they cannot adopt it in their day to day teaching and learning. By extension it can be inferred that even if there were to be internet facilities which will provide a wide database of information respondents without the right training they will be underutilized.

\section{Recommendations}

From the findings and conclusions of this study, the researcher strongly recommends that ICT basic resources like computers, laptops and infrastructures should be provided to the basic schools in Ajumako of the Central Region of Ghana for effective use of ICT in teaching and learning at the basic schools since it is the basic stage of equipping the youth with the necessary skills and knowledge for national development.

Teachers should be given the necessary training in ICT usage so that they become familiar with modern pedagogy of imparting knowledge and skills, and possible become part of curriculum structure for their professional training.

Again modern ICT laboratories should be built for basic schools to accommodate enough students at time looking at their population size for effective and efficient teaching and learning environment.

\section{Acknowledgements}

The research team wants to thank the editorial board of Fair East Publishers and also Antwi Abrefi Abigail (Law student at University of Professional Studies, Accra, Ghana) for her sound support and excellent contributions.

\section{Conflict of Interest Statement}

No conflict of interest has been declared by the authors.

\section{Funding}

The researchers have not received any support for the publication of this paper

\section{References}

Amedahe, F. K. (2010). Notes on Educational Research Methods. University of Cape Coast: Faculty of Education:

Ampofo, A. J. (2020). Contributions of the hospitality industry (hotels) in the development of Wa. International Journal of Advanced Economics, 2(2), 21-38.

Ampofo, A. J. (2020). Implications of poor waste disposal management practices on senior high schools within the Wa Municipality of Ghana. International Journal of Applied Research in Social Sciences, 2(3), 53-70. 
Ampofo, A. J. (2020). The nature of mortgage repayment plans in Ghana. Finance \& Accounting Research Journal, 2(3), 91-104.

Ampofo, A. J. (2020). Rural housing challenges in the Upper West Region of Ghana: A case study of Kulmasa. International Journal of Management \& Entrepreneurship Research, 2(4), 194-211.

Ampofo, A. J., \& Acheampong, B. (2019). Carrier decisions of Kadjebi Asato Senior High School Students and their choice of academic programmes: Lambert Academic Publishing.

Ampofo, A. J. (2019). Reading difficulties among class six pupils of Wa Basic School Complex: Lambert Academic Publishing.

Ampofo, A. J. (2019). Performance management and appraisal in improving teachers quality: Lambert Academic Publishing.

Becker, H. J., Ravitz, J.L., \& Wong, Y. (1999). Teacher and teacher-directed student use of computers and software. Irvine, CA: Center for Research on Information Technology and Organizations. Retrieved from http://www.crito.uci.edu/TLC/FINDINGS/COMPUTERUSE/REPORT_3_PDF_REV. PDF

Boakye, K.B., \& Banini, D.A. (2008). Teacher ICT Readiness in Ghana. In K. Toure, T.M.S. Tchombe, \& T. Karsent (Eds.), ICT and changing mindsets in education. ERNWACA / ROCARE.

Bork, A. (1980). Preparing student-computer dialogs: Advice to teachers. New York: Teachers College Press.

Bracey, B. (2005). "ICT: A powerful new tool to teach literacy". In Bracey, B., Culver, T., (Ed.)"Harnessing the Potential of ICT for Education- A Multistakeholder Approach" (Electronic version) United Nations ICT Task Force. Retrieved June 20, 2016, from http://www.digital_divide.net/ comm/docs/view.php? DocID =199

Dellit, J. (2002). Using ICT for Quality in Teaching - Learning Evaluation Processes. In Using ICT for Quality Teaching, Learning and Effective Management (p. 56). UNESCO Asia and Pacific Regional Bureau for Education. Retrieved June 8, 20016, from www2.unescobkk.org/elib/publications/aceidconf7/UsingICTQuality.pdf and www.ictliteracyinfo/rf.pdf/UsingICTQuality.pdf

Demetriadis, S., Barbas, A., Molohides, A., Palaigeorgiou, G., Psillos, D., Vlahavas, I., Tsoukalas, I., \& Pombortsis, A. (2003). Cultures in negotiation: Teachers' acceptance/resistance attitudes considering the infusion of technology into schools. Computers \& Education, 41, 19-37.

Harris, S. (2002). Innovative pedagogical practices using ICT in schools in England. Journal of Computer Assisted Learning, 18, 449-458.

Hennessy, S., Harrison, D., \& Wamakote, L. (2003). Teacher Factors Influencing Classroom Use of ICT in Sub-Saharan Africa. Itupale Online Journal of African Studies, 2(2) 3954.

Hepp, K. P., Hinostroza, S.E., Laval, M.E., Rehbein, L. F. (2004). Technology in schools: Education, ICT and the knowledge society. (Electronic version) OECD. Retrieved December 10, 2016, from www1.worldbank.org/education/pdf/ICT_report _oct04a.pdf 
Kozma, R., McGhee, R., Quellmalz, E., \& Zalles, D. (2004). Closing the digital divide: Evaluation of the World Links Programme. International Journal of Educational Development, 24(4), 361-381.

Lever-Duffy, J., McDonald J.B., \& Mizell, A.P. (2003). Teaching and learning with technology. Boston, MA: Pearson Education, Inc.

Martin, D. (2003). 'Relating the general to the particular: Data handling and historical learning'. In Haydn, T. \& Counsell, C. (Ed.), History, ICT and learning in the secondary school, (pp. 134-151). London: Routledge Falmer.

Moore, J. E. (2000). One road to turnover: An examination of work exhaustion in technology professionals. MIS Quarterly, 24(1), 141-148.

Munro, R. (2000). Exploring and explaining the past: ICT and History. Educational Media International, 37(4) 251-256.

Nichol, J., Watson, K., \& Waites, G. (2003). Rhetoric and reality: Using ICT to enhance pupil learning-Harry Potter and the Warley Woods mystery-Case study 2 British Journal of Educational Technology, 34(2), 151-167.

OECD. (2004). ICTs and economic growth in developing countries (Electronic version) OECD. Retrieved December 15, 2016, from http://www.oecd.org/dataoecd/15/54/34663175.pdf

Schoepp, K. (2005). Barriers to technology integration in technology-rich environment. Learning and teaching in Higher-Education: Gulf Perspectives, 2(1), 1-24.

Smeets, E. (2005). Does ICT contribute to powerful learning environments in primary

Tella, A., Tella, A., Toyobo, O. M., Adika, L. O., \& Adeyinka, A. A. (2007). An assessment of secondary school teachers' uses of ICTs: Implications for further development of ICT's use in Nigerian secondary schools. Retrieved $16^{\text {th }}$ October 2016, from http://www.cambridgetoafrica.org/resources/Hennessy\%20etal_FINAL.pdf

Thomas, G. (2003). Globalization of Educational Technology. Issues in Education, 23, 34-40.

Tomei, L. A. (2005). Taxonomy for the technology domain: A classification of educational objectives for the technology domain. Hershey, PA: Idea Group Publishers, Inc.

Wachira, E. (2005). "ICT in Education: A Practical Approach". In Bracey, B., Culver, T. (Eds.) "Harnessing the Potential of ICT for Education- A Multistakeholder Approach". United Nations ICT Task Force. Retrieved 10 $0^{\text {th }}$ October 2016 from http://www.digitaldivide.net/comm/docs/ view.php? DocID=199

Wellman, E., \& Flores, J. (2002). Online Discourse: Expansive Possibilities in the History.

Wijewardena, M. (2002). Assessment of existing empirical analyses of the underlying causes of the digital divide and Policy. Prescriptions to Deal with Such Underlying Causes of the Digital Divide -Ideas for Policy Makers. Communications Research Forum. British Journal of Educational Technology, 8(5), 311-321.

Zhao, Y., Pugh, K., Sheldon, S., \& Byers, J. L. (2002). Conditions for Classroom Technology Innovations. Teachers College Record, 104(3), 482-515. 